\title{
Sustaining environmental flows in water-deficient rivers via inter-basin hydropower transfer
}

\author{
Ting Gao ${ }^{1}$, Hongrui LIU ${ }^{1}$, Yuanyuan Sun $^{1}$, and Xinan Yin ${ }^{1}$ \\ ${ }^{1}$ Beijing Normal University
}

July 2, 2020

\begin{abstract}
In water-deficient rivers, environmental flows (e-flows) are usually sustained via inter-basin water transfer projects from watersufficient rivers, but these projects incur tremendous costs and may lead to many negative ecological effects, such as ecological invasion. This research proposed to transfer hydropower instead of water from water-sufficient rivers, because hydropower could substitute for water to promote economic development and reduce water withdrawal from water-deficient rivers. In this research, we established a computable general equilibrium model to analyze the substitution of hydropower for water in a water-deficient river basin, and determined the water withdrawal volume that could be reduced (conserved water). In addition, we adopted a range-of-variability approach to measure the effectiveness of e-flow provisions, and optimized the use of the conserved water to better maintain e-flows. The Luanhe River was adopted as a study case. The results showed that: the water-hydropower equivalent decreased as the transferred hydropower into the Luanhe River basin increased; a transferred hydropower amount of $22.46 \mathrm{kWh} / \mathrm{s}$, equivalent to $18.30 \mathrm{~m} 3 / \mathrm{s}$ conserved water, was optimal for the river basin; the conserved water should be distributed to the Luanhe River in the proportions of 0.55:0.1:0.35 during the wet, normal and dry seasons, respectively; the policy could transform the macro-economy toward a lower air-pollution pattern.
\end{abstract}

\section{Hosted file}

Main document-Sustaining environmental flows in water-deficient rivers via inter-basin hydropower trans available at https://authorea.com/users/339192/articles/465427-sustaining-environmentalflows-in-water-deficient-rivers-via-inter-basin-hydropower-transfer

Hosted file

Table1.docx available at https://authorea.com/users/339192/articles/465427-sustainingenvironmental-flows-in-water-deficient-rivers-via-inter-basin-hydropower-transfer

\section{Hosted file}

Table2.docx available at https://authorea.com/users/339192/articles/465427-sustainingenvironmental-flows-in-water-deficient-rivers-via-inter-basin-hydropower-transfer

Hosted file

Table3.docx available at https://authorea.com/users/339192/articles/465427-sustainingenvironmental-flows-in-water-deficient-rivers-via-inter-basin-hydropower-transfer 

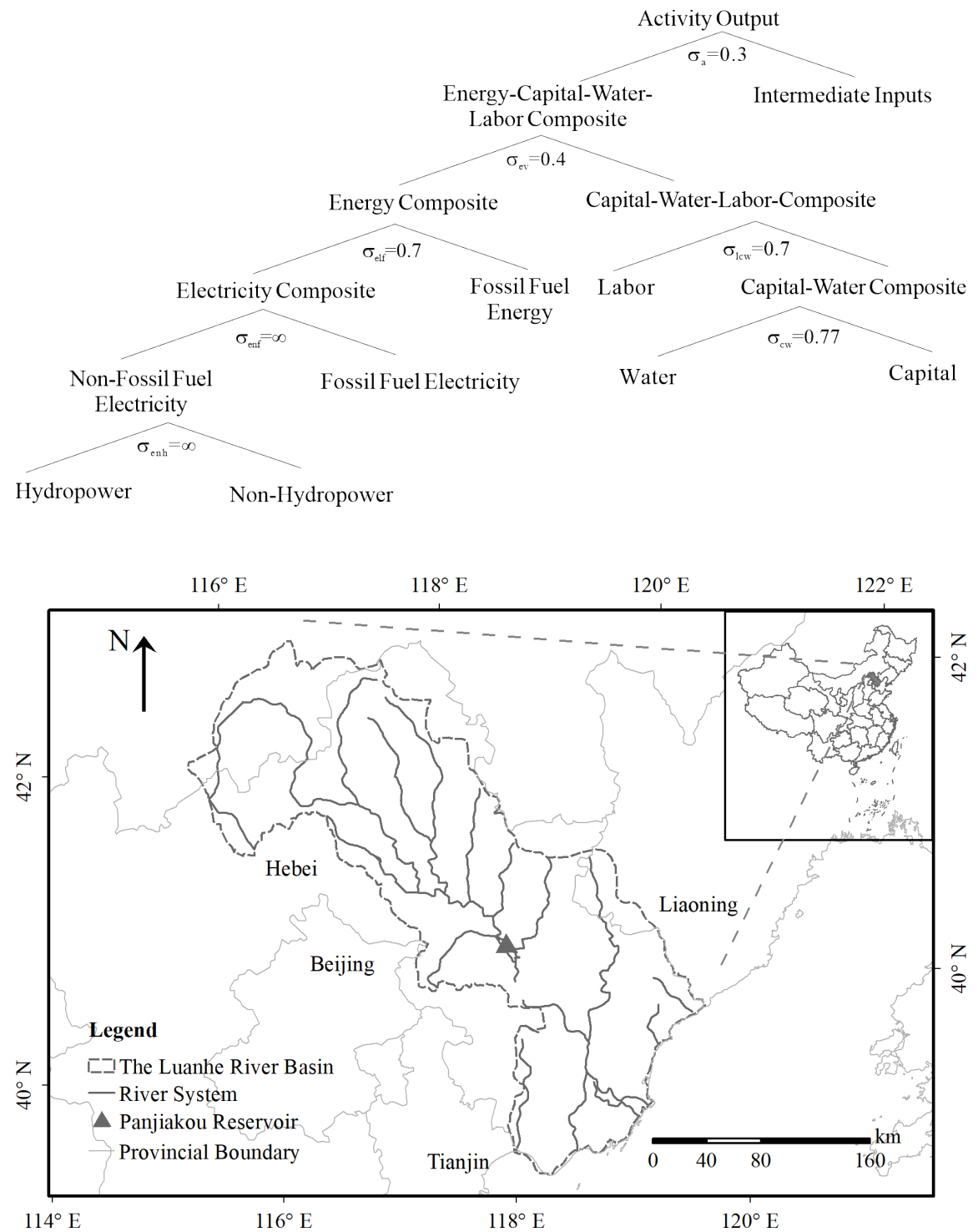

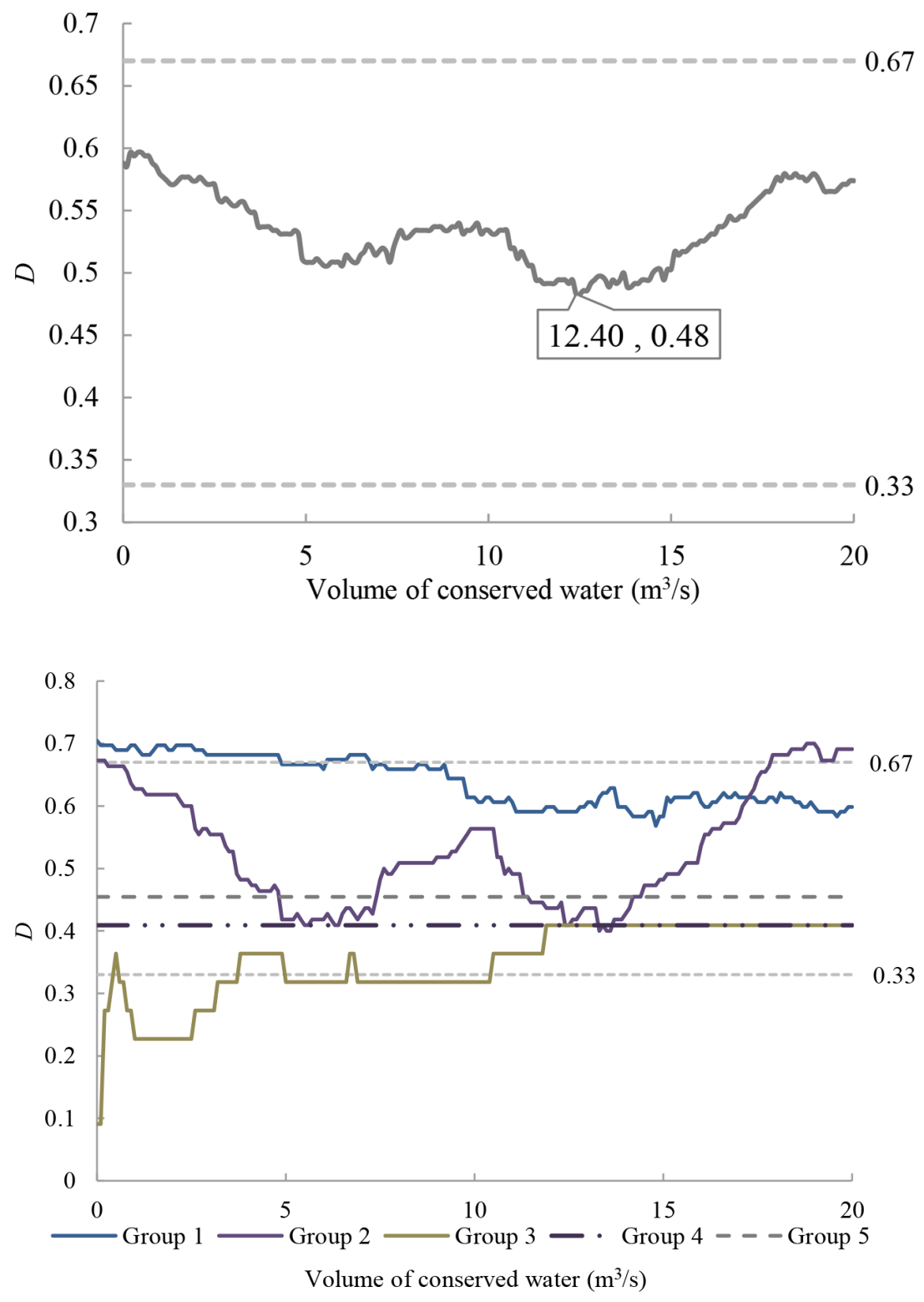

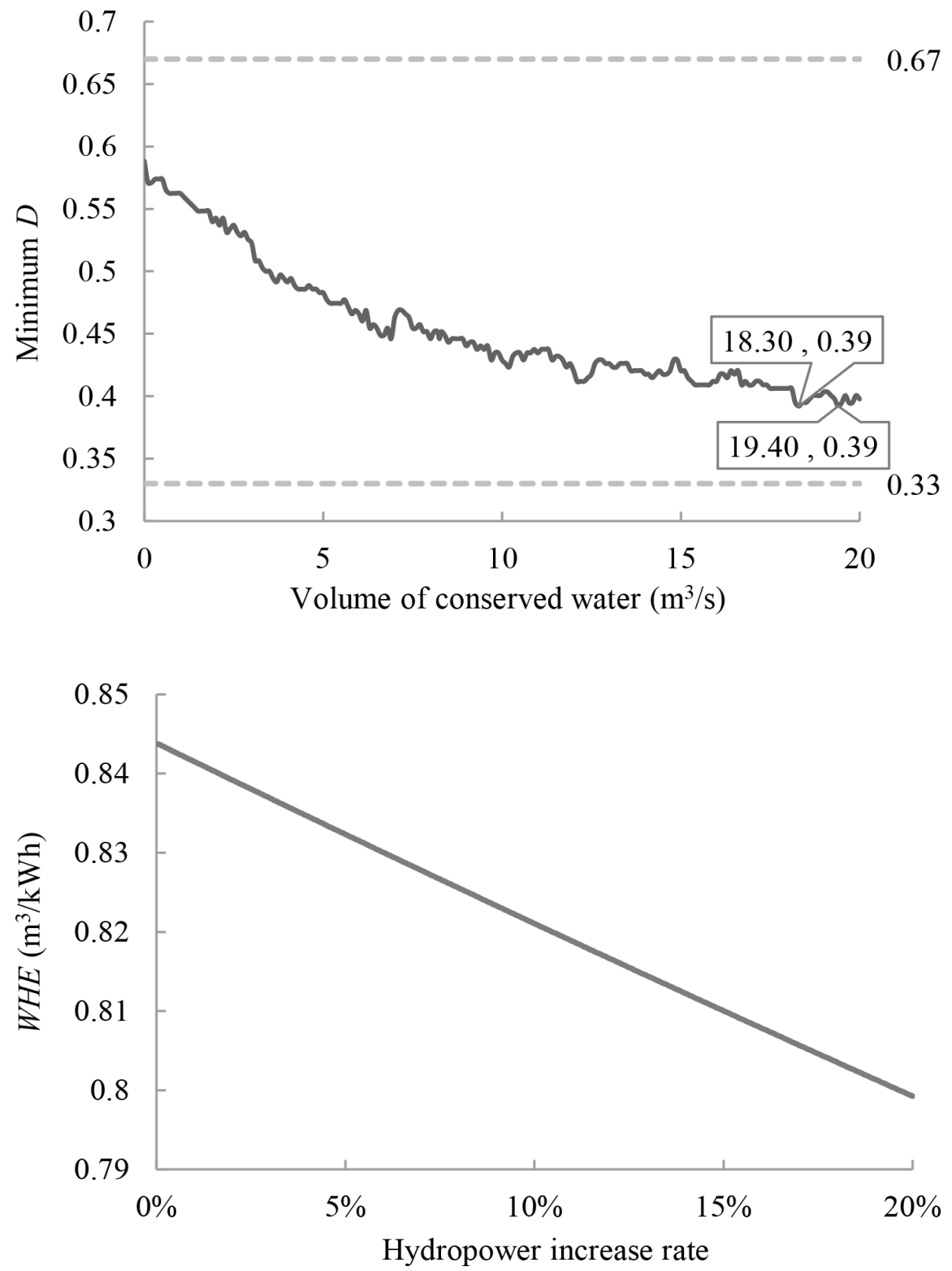


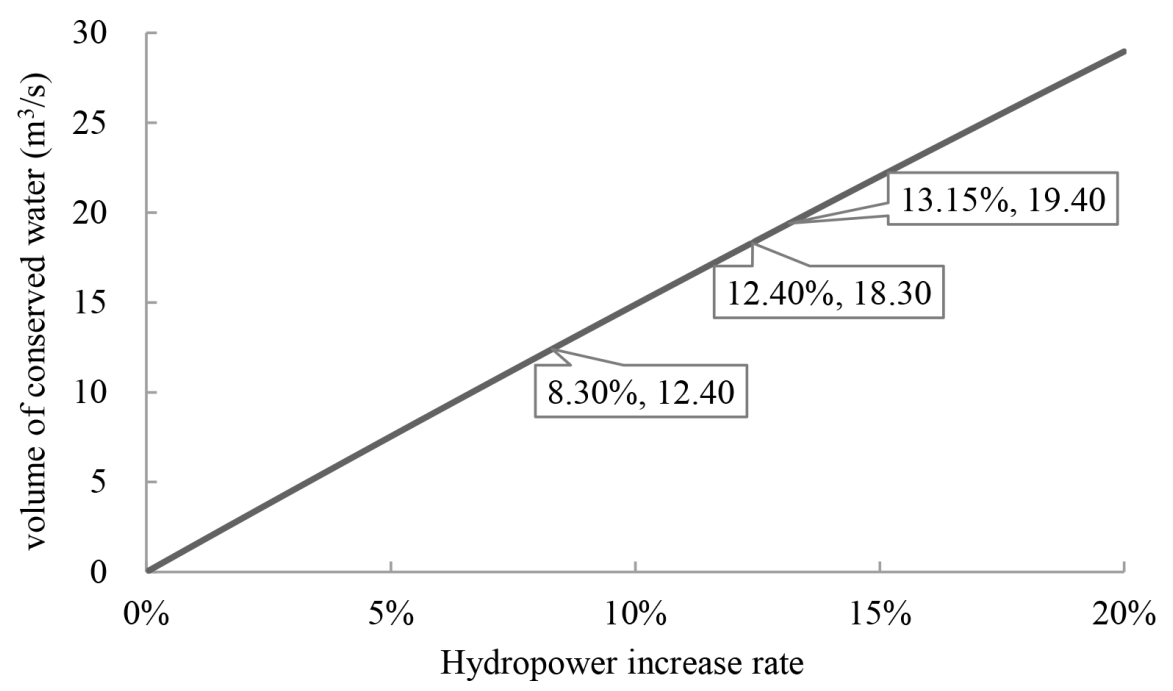

